Acta medico-historica Rigensia (2000) V: 413-415

DOI: 10.25143/amhr.2000.V.42

ACTA MEDICO-HISTORICA RIGENSIA V (XXIV)

\title{
А. С. ГЕОРГИЕВСКИЙ - ВРАЧ, УЧЕНЫЙ, ПЕДАГОГ
}

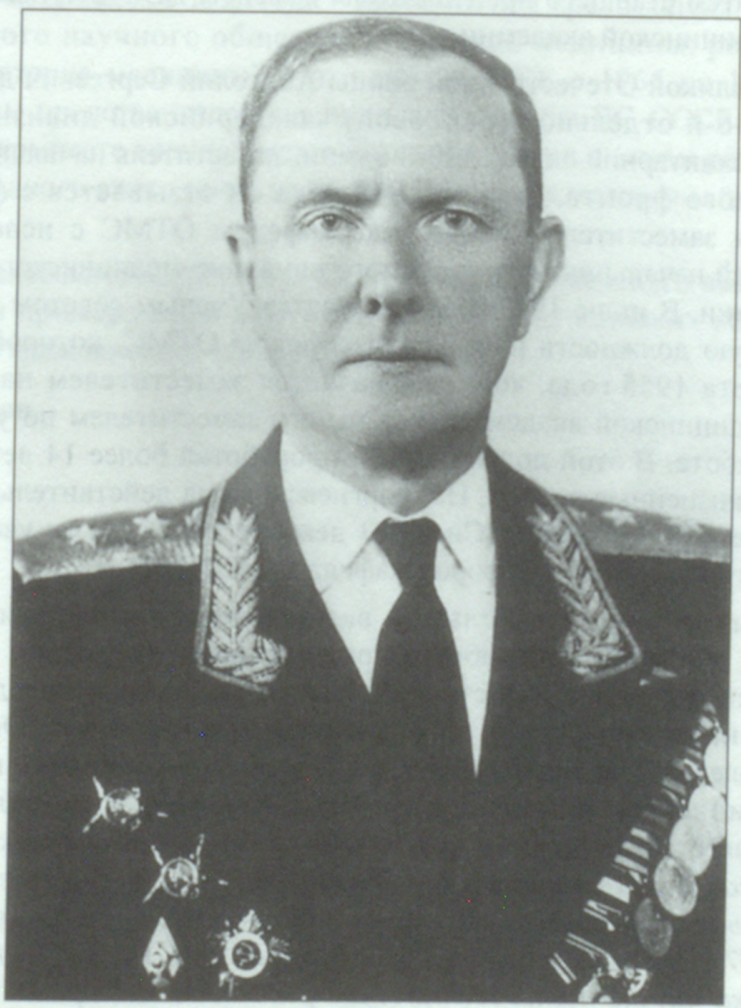

9 апреля 1998 года на 89-ом году жизни скончался бывший заместитель начальника Военно-медицинской академии по учебной и научной работе, почетный председатель Санкт-Петербургского научного общества историков медицины доктор медицинских наук профессор генерал-лейтенант в отставке участник Великой Отечественной войны Георгиевский Анатолий Сергеевич. 
За плечами Анатолия Сергеевича около 43 лет службы в Вооруженных Силах, многие годы научной, педагогической и общественной деятельности. Родился он в г. Новгороде в семье врача. В январе 1932 году он закончил Военно-медицинскую академию, после чего служил в войсках на различных врачебных должностях - младшего, затем старшего врача полка, начальника санитарной службы 29-й кавалерийской дивизии. В 1933 году А. С. Георгиевский поступил на заочный факультет Военной академии им. М. В. Фрунзе, которую успешно окончил в 1939 году. В 1937 году он возглавил школу санитарных инструкторов Белорусского особого военного округа, а в 1939 году назначен на должность преподавателя, затем старшего преподавателя кафедры ВВСД Куйбышевской Военно-медицинской академии.

В начале Великой Отечественной войны Анатолий Сергеевич дивизионный врач 46-й отдельной (рейдовой) кавалерийской дивизии, затем начальник санитарной службы 29-й армии, заместитель начальника ВСУ Калининского фронта. Весной 1943 года он отзывается с фронта и назначается заместителем начальника кафедры ОТМС с исполнением обязанностей начальника формируемого командно-медицинского факультета академии. В июне 1947 года избирается Ученым советом академии на вакантную должность начальника кафедры ОТМС, которой руководил до марта 1955 года, когда назначается заместителем начальника Военно-медицинской академии, а затем его заместителем по учебной и научной работе. В этой должности он проработал более 14 лет. Таковы основные жизненные вехи А. Н. Георгиевского на действительной военной службе в Вооруженных Силах. В декабре 1969 года он увольняется в запас и становится профессором кафедры ОТМС.

А. С. Георгиевский внес большой вклад в развитие теории военной медицины, особенно в разработке организационных проблем медицинского обеспечения войск, истории военной медицины, методологии и методики научно-исследовательской работы в медицине. Он автор и соавтор более 400 научных трудов, в числе которых учебники и учебные пособия, монографии, статьи в научных журналах и энциклопедиях. Хорошо известны такие монографии как “Исторический очерк развития медицинской службы армейских объединений” (Л., 1955), “Медицинская общественность и военная медицина в Освободительной войне на Балканах в 1877-1878 г2." (совм. с 3. В. Мицовым; М., 1978), “Методология и методика научно-исследовательской работы в медицине” (Л., 1981), "Советское зоравоохранение и военная медицина в Великой Отечественной войне 1941-1945 г2." (совм. с Н. Г. Ивановым и О. С. Лобастовым; Л., 1985). Под руководством Анатолия Сергеевича защищено 36 кандидатских и 24 докторских диссертаций. Более 20 его учеников (И. В. Алексанян, М.Ф. Войтенко, О.К.Гаврилов, Н.Г. Иванов, О. С. Лобастов, Г. Ревальд, А. Б. Хмыров, А. А. Шошин, Э. Штейнер и др.) в последующем 
возглавили самостоятельные научно-педагогические коллективы в академии, на военно-медицинских факультетах, в медицинских институтах нашей страны и некоторых иностранных государств (Польша, Болгария, Венгрия, ГДР).

Наряду с выполнением основных служебных обязанностей, А. С. Георгиевский всегда много внимания уделял различным видам общественной деятельности. С 1948 года по 1970 год он состоял членом Ученого медицинского совета ЦВМУ, с 1965 по 1975 год - членом пленума ВАК при Министерстве высшего и среднего образования СССР, более сорока лет был бессменным Председателем Ленинградского научного общества историков медицины, с 1959 года - заместителем председателя правления Всесоюзного научного общества историков медицины, редактором отдела "История медицины" 3-го издания БМЭ, с 1965 по 1970 год постоянным представителем медицинской службы ВС СССР в Международном комитете военной медицины и фармации, членом редколлегии международного ежегодника по теории и истории медицины "Асклетий" (София).

Жизнь и деятельность Анатолия Сергеевича Георгиевского всегда будет достойным примером для многих поколений медицинских работников военного и гражданского здравоохранения.

\section{B. С. Крутов}


